\title{
Early transcription of defence-related genes in Platanus $\times$ acerifolia leaves following treatment with cerato-platanin
}

\author{
I. BACCELLI ${ }^{1 *}$, A. SCALA ${ }^{1}$, L. PAZZAGLI ${ }^{2}$, and R. BERNARDI ${ }^{3}$ \\ Dipartimento di Scienze delle Produzioni Agroalimentari e dell'Ambiente ${ }^{1}$, Dipartimento di Scienze Biomediche \\ Cliniche e Sperimentali ${ }^{2}$, Università di Firenze, Firenze, 50134 Italy \\ Dipartimento di Scienze Agrarie, Alimentari e Agro-ambientali, Università di Pisa, Pisa, 56124 Italy $^{3}$
}

\begin{abstract}
The protein elicitor cerato-platanin (CP) is known to induce defence-related responses in various plants. Some of these responses occur very quickly. In the present work, transcriptional changes caused by $\mathrm{CP}$ in leaves from Platanus $\times$ acerifolia (Aiton) Willd. were studied. With a cDNA microarray, 131 differentially regulated transcripts were identified as responsive to $\mathrm{CP}$ after $24 \mathrm{~h}$ of treatment. Eighty-six of these were cold- or ozone-modulated transcripts, thus revealing a significant overlap between genes responsive to $\mathrm{CP}$ and to cold/ozone stress. The transcriptional changes caused by CP were compared with the CP-orthologous protein Pop1 in a time-course analysis performed after 3, 6, 12, and $24 \mathrm{~h}$ of treatment by real-time RT-PCR on five defence-related genes. Despite some differences, CP and Pop1 were both able to induce early transcriptional changes ( $W R K Y$ was overexpressed after only $3 \mathrm{~h}$ ) confirming that pathogenassociated molecular patterns (PAMPs) act very quickly on gene transcription.
\end{abstract}

Additional key words: cerato-populin, cold stress, ozone, plane tree, poplar, RT-PCR.

Plants can defend themselves from potential pathogenic microorganisms by two-level defence system. At a first level, plants recognise microbial molecules evolutionarily stable which are commonly known as pathogen- or microbe-associated molecular patterns (PAMPs or MAMPs); at a second level, if the pathogen overcomes the first layer of plant defences, a specific interaction between plant resistance proteins and pathogen effectors occurs (Jones and Dangl 2006). Few PAMPs have been described in detail until now, and most of these are microbial cell wall components. In fungi, an extensively studied example is represented by chitin (Schwessinger and Zipfel 2008). Perception of PAMPs by plant receptors causes very rapid responses. Among these, a substantial transcriptional reprogramming occurs (Anderson et al. 2010). Cerato-platanin (CP) is a small non-catalytic protein for which the current understanding of the experimental evidences suggests that it is a PAMP.

Cerato-platanin (CP) is produced by the ascomycete
Ceratocystis platani responsible for canker stain disease of plane trees, and belongs to the family, which takes its name from this protein, the "cerato-platanin family" (Pfam PF07249) (Pazzagli et al. 1999). CP is located in the cell wall of $C$. platani and is also abundantly excreted outside the fungal cells (Boddi et al. 2004, Scala et al. 2004, Bernardi et al. 2011). The structure of the protein and the pattern of its gene regulation suggest that the primary function of CP in the fungal life may be similar to that of expansins (De Oliveira et al. 2011, Baccelli et al. 2012).

When applied on host or non-host plants, CP elicits defence-related responses; in Platanus $\times$ acerifolia leaves it causes production of hydrogen peroxide, nitric oxide, phytoalexins, and phenolic compounds, causes overexpression of defence-related genes, localised resistance, and cell plasmolysis as a result of programmed cell death (Pazzagli et al. 1999, Scala et al. 2004, Bennici et al. 2005, Lombardi et al. 2010). Content of phytoalexins begin to rise between 12 and $24 \mathrm{~h}$ after treatment with

Received 28 February 2012, accepted 2 November 2012.

Abbreviations: CP - cerato-platanin; PAMP - pathogen-associated molecular pattern; Pop1 - cerato-populin; RT-PCR - reverse transcriptase - polymerase chain reaction.

Acknowledgments: The work was supported by the Ministero Italiano dell'Università e della Ricerca Scientifica, Progetti di Ricerca di Interesse Nazionale 2009.

* Corresponding author; fax: (+39) 0554573232, e-mail: ivan.baccelli@unifi.it 


\section{BACCELLI et al.}

CP; cyto-histological responses occur after $24 \mathrm{~h}$; at the same time, the germination of $C$. platani conidia on the leaf surface is prevented (Bennici et al. 2005, Fontana et al. 2008). As CP-induced defence-related genes were identified from $P$. acerifolia leaves treated for $48 \mathrm{~h}$ (Baccelli et al. 2008, Fontana et al. 2008), the present study is focused on the transcriptional changes occurring during the first $24 \mathrm{~h}$ of treatment.

Due to the fact that the Platanus genome has not yet been sequenced and few plane tree genes are available in GenBank, in order to increase the number of genes to be analysed, we designed a cDNA microarray containing both plane tree and poplar transcripts. Poplar is a species genetically related to plane tree, and differentially regulated transcripts from poplar leaves stressed with ozone and cold were available at the Department of Crop Biology of the University of Pisa. The cDNA microarray was used to identify differentially regulated genes after $24 \mathrm{~h}$ of treatment with CP on the basis of the existence of a significant overlap among genes expressed in response to different stresses (Shinozaki and Yamaguchi-Shinozaki 2000, Rabbani et al. 2003, Francia et al. 2007, Orsini et al. 2010). Five defence-related genes were further studied after $3,6,12$, and $24 \mathrm{~h}$ of treatment by real-time reverse transcriptase - polymerase chain reaction (RT-PCR) comparing the eliciting activity of CP with cerato-populin (Pop1), a CP-orthologous protein from C. populicola, with PAMP activity on plane tree (Comparini et al. 2009).

A total of 318 cDNA sequences (library clones), grouped as follows, were spotted on microarray glass slides by MicroCRIBI (University of Padoa, Italy): 56 poplar clones induced by ozone (Rizzo et al. 2007); 162 poplar clones induced by cold (Maestrini et al. 2009); and 100 plane tree clones induced by CP after $48 \mathrm{~h}$ of treatment and isolated in previous works (Baccelli et al. 2008, Fontana et al. 2008). The spots area was 15480 $\times 15480 \mu \mathrm{m}$, and the array was made up of 16 squares, each made up of 13 rows and 10 columns. Each spot was $85 \mu \mathrm{m}$ diameter and $220 \mu \mathrm{m}$ spaced. Each probe was deposited in 4 replicates.

For the microarray analysis, total RNA was extracted from detached $P$. acerifolia leaves treated according to Fontana et al. (2008) with minor modifications. Different leaves were treated with 10 drops $\left(1 \mathrm{~mm}^{3}\right)$ containing $150 \mu \mathrm{M} \mathrm{CP}$ (treated sample) or sterile distilled water as a control sample, and incubated in a moist chamber for $24 \mathrm{~h}$. Cetyltrimethylammonium bromide (CTAB) buffer was used to extract total RNA from leaves according to Fontana et al. (2008) without performing the $\mathrm{CsCl}$ gradient, and amplification grade DNase I (SigmaAldrich, St Louis, MO, USA) was used to remove DNA contamination. Total RNA was reverse transcribed, labelled, and subjected to the hybridization steps as described by Trainotti et al. (2007). The cDNA microarray was scanned by MicroCRIBI service with a two-channel confocal microarray scanner (ScanArray ${ }^{\circledR}$ Lite, Perkin Elmer, MA, USA) using its dedicated software (ScanArray Express 3.0.0). Raw data was normalized by using total algorithm and the spots with intensity close to background noise were eliminated. Differentially expressed genes were obtained using One Class SAM (significance analysis of microarray, by Tusher et al. 2001) with false discovery rate (FDR) $0 \%$. A functional classification of the differentially regulated genes was made according to Fontana et al. (2008).

In order to validate the microarray result and to study the gene regulation induced by $\mathrm{CP}$ and Pop1 in early time-points, real-time quantitative RT-PCRs (qRT-PCRs) were performed on RNA extracted from $P$. acerifolia leaves treated for $3,6,12$, and $24 \mathrm{~h}$ with $150 \mu \mathrm{M} \mathrm{CP}$, Pop1, or water, as described above. RNA was transcribed into cDNA (400 ng per sample) as described by Bernardi et al. (2011) and transcripts codifying well known defence- or stress-related genes were analysed: $\beta$-1,3-glucanase (pathogenesis-related protein 2, PR-2), thaumatin protein (PR-5), and lipid transfer protein (PR-14) (Van Loon et al. 2006); and the transcription factor WRKY (Eulgem 2005) and the ThiF family protein, also known as ubiquitin activating enzyme, whose importance in the plant innate immunity has been recently reported (Balaji et al. 2011).

For WRKY and ThiF, whose cDNAs spotted on the microarray belonged to poplar, the orthologous partial sequences from $P$. acerifolia were isolated (GenBank acc. Nos. HE651262 and HE651263). The same RNA used to perform the microarray analysis was used to validate the result whereas three different biological replicates were used to compare $\mathrm{CP}$ and Pop1. The following genespecific primers were used:

PR2-F 5'-CCTTGTTTACAGCCCCATCAG-3', PR2-R 5'- GAACCACCCGCCTTCTCAA-3'; PR14-F 5'-CACTCAACAACGACGCTAAAACC-3', PR14-R 5'-CGGACTCTCACCACATCTCATC-3'; PR5-F 5'-CGGTGCTTACGGCAATCC-3', PR5-R 5'-GGGCATGCGTTCTTGAAGA-3'; ThiF-F 5'-GGATCTGGTGCTGAGTTGTGTAGA-3', Thif-R 5'-GCTCATTGCAAGCCTGGTTT-3'; WRKY-F 5'-TTGCCCAGTCAAGAAGAAGGTT-3', WRKY-R 5'-GAGAAGGGTGTGGGTGGTTGT-3'.

The $18 S$ rRNA gene was used as endogenous control for its transcriptional stability (Fontana et al. 2008, Bernardi et al. 2011). The gene-specific primers for $18 \mathrm{~S}$ were: 18S-F 5'-GGCGGATGTTGCTTTTAGGA-3', 18S-R 5'-TTCAGCCTTGCGACCATACTC-3'.

The amplifications of the target gene and the endogenous control were run in triplicate on the same plate in separate tubes. Reactions $\left(20 \mathrm{~mm}^{3}\right)$ were carried out with $20 \mathrm{ng}$ of cDNA as template, primers $200 \mathrm{nM}$ each, and $1 \times$ Fast SYBR Green ${ }^{\circledR}$ Master Mix (Applied Biosystems, Foster City, CA, USA) following the manufacturer's instructions. PCRs were run in a StepOne ${ }^{\mathrm{TM}}$ real-time PCR System (Applied Biosystems) using the recommended thermal-cycling conditions for the fast mode (hold $95^{\circ} \mathrm{C}$, $20 \mathrm{~s} ; 40$ cycles $\left.95{ }^{\circ} \mathrm{C}, 3 \mathrm{~s} ; 60{ }^{\circ} \mathrm{C}, 30 \mathrm{~s}\right)$. The size of the amplification products was checked on agarose gel. Before the quantification, a validation experiment was performed to ensure that the amplification efficiencies of 
the target and the reference genes were approximately equal. The relative amount of target in each sample was determined using the comparative $\mathrm{C}_{\mathrm{T}}$ method as described in the ABI PRISM 7700 sequence detection system user bulletin \#2 (Applied Biosystems). By this method, the amount of target normalized to the endogenous reference and relative to a calibrator sample is given by the arithmetic formula $2^{-\Delta \Delta \mathrm{Ct}}(\mathrm{Ct}$, threshold cycle). The obtained $2^{-\Delta \Delta \mathrm{Ct}}$ values (or fold-change values) were expressed as $\log _{2}$, so that the relative amount of target in the treated samples (CP- or Pop1-treated) acquired positive values for the up-regulated transcripts and negative values for those down-regulated, compared to the respective water-treated control samples which had $\log _{2}$ values $=0$ (not shown in the tables).

Out of 318 cDNA sequences present on the microarray, 131 turned out to be differentially regulated in $P$. acerifolia leaves treated with $\mathrm{CP}$ for $24 \mathrm{~h}$ : 71 transcripts were up-regulated and 60 were downregulated (Fig. 1A,B). Out of the 131 modulated transcripts, 45 were plane tree clones and 86 were poplar clones (transcripts list available at www.wuala.com/ IvanBaccelli/Documenti/Supplement.doc/) and thus the cross-species hybridization allowed identification of 86 new sequences of $P$. acerifolia differentially regulated by $\mathrm{CP}$. Given the origin of the poplar clones, the result revealed a significant overlap between genes responsive to different stresses. Well known defence- or stressrelated genes were identified as responsive to $\mathrm{CP}$ and to cold/ozone stress like those codifying metallothioneins (Choi et al. 1996), WRKY (Eulgem 2005), and ThiF (Balaji et al. 2011). Of these genes, 35 were up-regulated and 51 down-regulated by $\mathrm{CP}$.

\section{A up-regulated (71)}

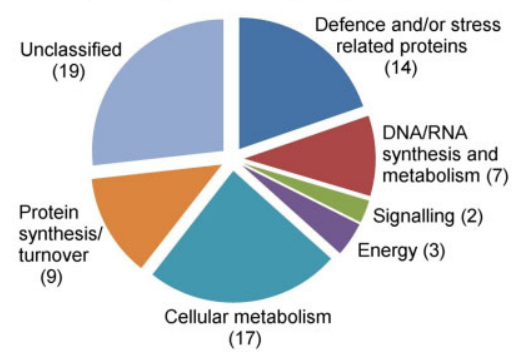

B down-regulated (60)

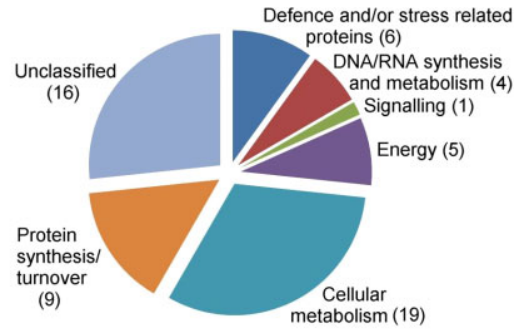

Fig. 1. Microarray result. Functional classification of the cDNA sequences differentially regulated in $P$. acerifolia leaves treated with $\mathrm{CP}$ for $24 \mathrm{~h}$ : up-regulated $(A)$ and down-regulated $(B)$ transcripts.
Table 1. Comparison between gene expression (relative values) in CP-treated leaves obtained by microarray analysis and realtime RT-PCR on five selected transcripts: PR-2 (pathogenesisrelated protein 2, $\beta-1,3$ glucanase), PR-5 (thaumatin), PR-14 (lipid transfer protein), ThiF family protein, and transcription factor WRKY. Relative expression values are reported as $\log _{2}$ fold change. Negative values mean down-regulation. Water treated leaves were used as control ( $\log _{2}=0$, not shown).

\begin{tabular}{llcc}
\hline Accession & Gene & Microarray & qRT-PCR \\
\hline AM260509 & $P R-2$ & 0.2 & 2.5 \\
FN821454 & $P R-5$ & 0 & -0.1 \\
AM286249 & $P R-14$ & -1.1 & -1.4 \\
HE651263 & ThiF & 1.2 & 0.7 \\
HE651262 & WRKY & 0.3 & 0.4 \\
\hline
\end{tabular}

Table 2. Expression analysis performed with real-time RT-PCR in $P$. acerifolia leaves treated for $3,6,12$, or $24 \mathrm{~h}$ with ceratoplatanin $(\mathrm{CP})$ or cerato-populin (Pop1). Five defence-related genes were analyzed: $P R-2, P R-5, P R-14, T h i F$, and $W R K Y$. Relative expression values are reported as $\log _{2}$ fold change. Negative values mean down-regulation. Means $\pm \mathrm{SD}, n=3$, * - significant difference at $P<0.05$ between treated and control leaves (unpaired $t$-test performed using GraphPad InStat v. 3.05 (GraphPad Software, San Diego, CA, USA).

\begin{tabular}{cllclc}
\hline Gene & Elicitor & $3 \mathrm{~h}$ & $6 \mathrm{~h}$ & $12 \mathrm{~h}$ & $24 \mathrm{~h}$ \\
\hline$P R-2$ & CP & $2.5 \pm 1.0^{*}-0.1 \pm 0.4$ & $0.2 \pm 0.3$ & $4.7 \pm 2.1^{*}$ \\
& Pop1 & $0.6 \pm 0.9$ & $0.8 \pm 0.0^{*}$ & $0.5 \pm 0.6$ & $2.2 \pm 0.6^{*}$ \\
$P R-5$ & CP & $0.0 \pm 0.0$ & $2.4 \pm 0.7^{*}$ & $0.4 \pm 0.7$ & $-0.5 \pm 0.8$ \\
& Pop1 & $0.9 \pm 0.3^{*}$ & $2.0 \pm 1.0^{*}$ & $0.7 \pm 0.3^{*}$ & $1.0 \pm 0.3^{*}$ \\
PR-14 CP & $-0.1 \pm 0.4$ & $-2.1 \pm 0.8^{*}$ & $-0.2 \pm 0.3$ & $-2.1 \pm 1.0^{*}$ \\
& Pop1 & $-0.4 \pm 0.7$ & $-2.5 \pm 1.1^{*}$ & $-0.2 \pm 0.8$ & $-0.5 \pm 0.8$ \\
$T h i F$ & CP & $-0.4 \pm 0.1^{*}$ & $0.8 \pm 0.5^{*}$ & $-0.1 \pm 0.4$ & $0.4 \pm 0.2^{*}$ \\
& Pop1 & $0.4 \pm 0.0^{*}$ & $0.6 \pm 0.0^{*}$ & $0.2 \pm 0.0^{*}$ & $-0.6 \pm 0.3^{*}$ \\
WRKY CP & $1.6 \pm 1.0^{*}$ & $0.7 \pm 0.4^{*}$ & $0.6 \pm 0.0^{*}$ & $1.5 \pm 0.9^{*}$ \\
& Pop1 & $1.9 \pm 0.2^{*}$ & $0.7 \pm 0.1^{*}$ & $0.5 \pm 0.3^{*}$ & $0.3 \pm 0.1^{*}$ \\
\end{tabular}

Regarding the plane tree clones spotted on the microarray, these represented transcripts already known to be up-regulated by $\mathrm{CP}$, but after a longer treatment (48 h). Interestingly, out of 100 clones present on the microarray, 55 were not modulated in the present study, 9 were down-regulated, and only 36 were up-regulated. This result showed unequivocally that the gene modulation undergoes remarkable changes over time after treatment with CP.

The microarray result was confirmed by qRT-PCRs performed on defence-related genes: three plane tree clones $(P R-2, P R-14$ and $P R-5)$ and two poplar clones (ThiF and WRKY). One of these (PR-5) was selected as it did not show modulation. Although with some differences, qPCR data was consistent with that of microarray. This also occurred for ThiF and WRKY, thus confirming the possibility of cross-species hybridization (Table 1). 


\section{BACCELLI et al.}

The same transcripts used to validate the microarray result were also analysed after $3,6,12$, and $24 \mathrm{~h}$ of treatment. Since it is known that a significant overlap exists in transcriptional regulation by different PAMPs (Schwessinger and Zipfel 2008), both CP and Pop1 were used to separately treat plane tree leaves at the different time-points. In a previous work, the ability of Pop1 to induce production of phenolic compounds in plane tree leaves after $24 \mathrm{~h}$ of treatment had been reported (Comparini et al. 2009). Both CP and Pop1 were able to cause very early changes at the level of gene transcription in plane tree leaves confirming that the transcriptional changes induced by PAMPs occur during the first hours after their perception (Schwessinger and Zipfel 2008, Anderson et al. 2010). Six hours was the treatment time where the modulation induced by the proteins was the most similar, with PR-5, ThiF, and WRKY that were upregulated, and $P R-14$ that was down-regulated (Table 2). However, after only $3 \mathrm{~h}, W R K Y$ was induced by both CP and Pop1, $P R-2$ was induced only by CP; and $P R-5$ and ThiF were induced only by Pop1. Thus, the result showed a different timing in gene induction between $\mathrm{CP}$ and Pop1. Unlike $P R-2$ and $P R-5, P R-14$ was never upregulated during the first $24 \mathrm{~h}$ of treatment, either by $\mathrm{CP}$ or by Pop1, although Fontana et al. (2008) reported an up-regulation by $\mathrm{CP}$ after $48 \mathrm{~h}$. However, downregulations of lipid transfer proteins under stress are also reported in other studies (Carvalho et al. 2006).

Overall, the different modulation pattern shown by $\mathrm{CP}$ and Pop1 over time was in accordance with preliminary data by Lombardi et al. (2010) which found differences between CP and Pop1 in timing of activation of defence responses. A difference in timing and amplitude of gene induction could be due to differences in the $3 \mathrm{D}$ structure of the two proteins and might be helpful in the future in order to define a structure-function relationship.

\section{References}

Anderson, J.P., Gleason, C.A., Foley, R.C., Thrall, P.H., Burdon, J.B., Singh, K.B.: Plants versus pathogens: an evolutionary arms race. - Funct. Plant Biol. 37: 499-512, 2010.

Baccelli, I., Fontana, F., Scala, A., Pazzagli, L., Cappugi, G., Salvini, M., Durante, M., Bernardi, R.: Modulation of gene expression induced in Platanus acerifolia by cerato-platanin and conidial suspension of Ceratocystis platani. - In: Proceedings $52^{\text {nd }}$ Italian Society of Agricultural Genetics Annual Congress. Pp. C.10. SIGA, Padova 2008.

Baccelli, I., Comparini, C., Bettini, P.P., Martellini, F., Ruocco, M., Pazzagli, L., Bernardi, R., Scala, A.: The expression of the cerato-platanin gene is related to hyphal growth and chlamydospores formation in Ceratocystis platani. - FEMS Microbiol. Lett. 327: 155-163, 2012.

Balaji, V., Sessa, G., Smart, C.D.: Silencing of host basal defense response-related gene expression increases susceptibility of Nicotiana benthamiana to Clavibacter michiganensis subsp. michiganensis. - Phytopathology 101: 349-357, 2011.

Bennici, A., Calamassi, R., Pazzagli, L., Comparini, C., Schiff, S., Bovelli, R., Mori, B., Tani, C., Scala, A.: Cytological and ultrastructural responses of Platanus acerifolia (Ait.) Willd. leaves to cerato-platanin, a protein from Ceratocystis fimbriata f. sp. platani. - Phytopathol. Mediterr. 44: 153$161,2005$.

Bernardi, R., Baccelli, I., Carresi, L., Comparini, C., Pazzagli, L., Scala, A.: Cerato-platanin elicits transcription of defence-related genes earlier than Ceratocystis platani on Platanus acerifolia. - Forest Pathol. 41: 255-261, 2011.

Boddi, S., Comparini, C., Calamassi, R., Pazzagli, L., Cappugi, G., Scala, A.: Cerato-platanin protein is located in the cell walls of ascospores, conidia and hyphae of Ceratocystis fimbriata f. sp. platani. - FEMS Microbiol. Lett. 233: 341346, 2004.

Carvalho, A.O., Souza-Filho, G.A., Ferreira, B.S., Branco, A.T., Araújo, I.S., Fernandes, K.V.S., Retamal, C.A., Gomes, V.M.: Cloning and characterization of a cowpea seed lipid transfer protein cDNA: expression analysis during seed development and under fungal and cold stresses in

seedlings' tissues - Plant Physiol. Biochem. 44: 732-742, 2006.

Choi, D., Kim, H.M., Yun, H.K., Park, J.A., Kim, W.T., Bok, S.H.: Molecular cloning of a metallothionein-like gene from Nicotiana glutinosa $\mathrm{L}$ and its induction by wounding and tobacco mosaic virus infection. - Plant Physiol. 112: 353359, 1996.

Comparini, C., Carresi, L., Pagni, E., Sbrana, F., Sebastiani, F., Luchi, N., Santini, A., Capretti, P., Tiribilli, B., Pazzagli, L., Cappugi, G., Scala, A.: New proteins orthologous to ceratoplatanin in various Ceratocystis species and the purification and characterization of cerato-populin from Ceratocystis populicola. - Appl. Microbiol. Biotechnol. 84: 309-322, 2009.

De Oliveira, A.L., Gallo, M., Pazzagli, L., Benedetti, C.E., Cappugi, G., Scala, A., Pantera, B., Spisni, A., Pertinhez, T.A., Cicero, D.O.: The structure of the elicitor ceratoplatanin $(\mathrm{CP})$, the first member of the $\mathrm{CP}$ fungal protein family, reveals a double- $\psi \beta$-barrel fold and carbohydrate binding. - J. biol. Chem. 286: 17560-17568, 2011.

Eulgem, T.: Regulation of the Arabidopsis defense transcriptome. - Trends Plant Sci. 10: 71-78, 2005.

Fontana, F., Santini, A., Salvini, M., Pazzagli, L., Cappugi, G., Scala, A., Durante, M., Bernardi, R.: Cerato-platanin treated plane tree leaves restrict Ceratocystis platani growth and overexpress defence-related genes. - J. Plant Pathol. 90: 293-304, 2008.

Francia, D., Demaria, D., Calderini, O., Ferraris, L., Valentino, D., Arcioni S., Tamietti, G., Cardinale, F.: Wounding induces resistance to pathogens with different lifestyles in tomato: role of ethylene in cross-protection. - Plant Cell Environ. 30: 1357-1365, 2007.

Jones, J.D.G., Dangl, J.L.: The plant immune system. - Nature 444: 323-329, 2006

Lombardi, L., Baccelli, I., Bernardi, R., Cappugi, G., Pazzagli, L., Picciarelli, P., Scala, A.: Cerato-platanin and ceratopopulin induce differential resistance responses in plane tree leaves. - J. Plant Pathol. 92 (Suppl.): S4.87, 2010.

Maestrini, P., Cavallini, A., Rizzo, M., Giordani, T., Bernardi, R., Durante, M., Natali, L.: Isolation and expression 
analysis of low temperature-induced genes in white poplar (Populus alba). - J. Plant Physiol. 166: 1544-1556, 2009.

Orsini, F., Cascone, P., De Pascale, S., Barbieri, G., Corrado, G., Rao, R., Maggio, A.: Systemin-dependent salinity tolerance in tomato: evidence of specific convergence of abiotic and biotic stress responses. - Physiol. Plant. 138: 1021, 2010.

Pazzagli, L., Cappugi, G., Manao, G., Camici, G., Santini, A., Scala, A.: Purification, characterization, and amino acid sequence of cerato-platanin, a new phytotoxic protein from Ceratocystis fimbriata f. sp. platani. - J. biol. Chem. 274: 24959-24964, 1999.

Rabbani, M.A., Kyonoshin, M., Hiroshi, A., Khan, M.A., Katsura, K., Ito, Y., Yoshiwara, K., Seki, M., Shinozaki, K., Yamaguchi-Shinozaki, K.: Monitoring expression profiles of rice genes under cold, drought, and high-salinity stresses and abscisic acid application using cDNA microarray and RNA gel-blot analyses. - Plant Physiol. 133: 1755-1767, 2003.

Rizzo, M., Bernardi, R., Salvini, M., Nali, C., Lorenzini, G., Durante, M.: Identification of differentially expressed genes induced by ozone stress in sensitive and tolerant poplar hybrids. - J. Plant Physiol. 164: 945-949, 2007.
Scala, A., Pazzagli, L., Comparini, C., Santini, A., Tegli, S., Cappugi, G.: Cerato-platanin, an early-produced protein by Ceratocystis fimbriata f. sp. platani, elicits phytoalexin synthesis in host and non-host plants. - J. Plant Pathol. 86: 23-29, 2004.

Schwessinger, B., Zipfel, C.: News from the frontline: recent insights into PAMP-triggered immunity in plants. - Curr. Opin. Plant Biol. 11: 389-395, 2008.

Shinozaki, K., Yamaguchi-Shinozaki, K.: Molecular responses to dehydration and low temperature: differences and crosstalk between two stress signaling pathways. - Curr. Opin. Plant Biol. 3: 217-223, 2000.

Trainotti, L., Tadiello, A., Casadoro, G.: The involvement of auxin in the ripening of climacteric fruits comes of age: the hormone plays a role of its own and has an intense interplay with ethylene in ripening peaches. - J. exp. Bot. 58: 32993308, 2007.

Tusher, V.G., Tibshirani, R., Chu, G.: Significance analysis of microarrays applied to the ionizing radiation response. Proc. nat. Acad. Sci. USA 98: 5116-5121, 2001.

Van Loon, L.C., Rep, M., Pieterse1, C.M.J.: Significance of inducible defense-related proteins in infected plants. - Annu. Rev. Phytopathol. 44:135-162, 2006. 